\title{
28. MINERALOGY AND GEOCHEMISTRY OF ALTERATION PRODUCTS IN LEG 81 BASALTS ${ }^{1}$
}

\author{
A. Desprairies and C. Bonnot-Courtois, Université de Paris-Sud \\ C. Jehanno, Centre des Faibles Radioactivités, CEA-CNRS \\ S. Vernhet, Université de Paris-Sud \\ and \\ J. L. Joron, Laboratoire P. Süe, CNRS-CEN²
}

\begin{abstract}
Alteration products of basalts from the four holes drilled during Leg 81 were studied and found to be characterized by the widespread occurrence of trioctahedral clay minerals ( $\mathrm{Mg}$ smectite to chlorite). In some cases zeolites (analcite, chabazite) are associated with the saponite. A more oxidizing stage is marked by a saponite-celadonite association, presenting the geochemical characteristics of hydrothermal processes. Later stages of alteration are represented by palagonitization and subaerial weathering at two sites. These different alteration processes of basalts from Leg 81 record the paleoenvironment during the first opening stages of the Northeast Atlantic Ocean in the Paleocene-Eocene periods.
\end{abstract}

\section{INTRODUCTION}

Basalt samples showing various degrees of alteration were recovered from the four holes drilled during Leg 81 (Fig. 1). The petrography, mineralogy, and geochemistry of the fresh basaltic samples were studied by Joron et al. (this volume) and show that they are strongly light rare earth element (LREE)-depleted oceanic tholeiites. This study is concerned with the secondary minerals and products formed from the interstitial glass and filling vesicles and veins. First, weathering products will be described for each hole, and afterward, a comparison between the four sites will provide information about the basaltic setting of the Rockall margin during the Paleocene.

\section{ANALYTICAL PROCEDURE}

Several techniques were used to gather and analyze the mineralogi$\mathrm{cal}$ and geochemical data. A scanning electron microscope (CAMEBAX) with an X-ray dispersive spectrometer (EDAX) was used for studying morphology and for performing mineral analysis (by point) and bulk analysis of samples for areas of several square millimeters. The semiquantitative analysis is conducted with a nonautomatic ZAF program, using standard minerals (USGS Rock Standards, Flanagan, 1976).

The relative errors for smooth surfaces are (1) better than $5 \%$ for elements with concentrations over $10 \%$, (2) $10 \%$ for elements with concentrations between 5 and $10 \%$, (3) approximately $20 \%$ for elements with concentrations below $5 \%$.

The detection limit is $1000 \mathrm{ppm}(0.1 \%)$. The data reported in the tables are typical analyses of a facies or a group of minerals. Several typical analyses are reported if an important variation appears.

$\mathrm{X}$-ray mineralogy determinations were performed on bulk samples or on the clay fraction $(<2 \mu \mathrm{m})$ with a diffractometer system equipped with a monochromator $\left(\mathrm{CoK}_{\alpha}\right.$ radiation).

Some transition elements were measured by atomic absorption spectrometry. The analytical error is $<1 \%$ for $\mathrm{Mn}$ and between 5 and $10 \%$ for $\mathrm{Cu}, \mathrm{Co}$, and $\mathrm{Ni}$.

\footnotetext{
${ }^{1}$ Roberts, D. G., Schnitker, D., et al., Init. Repts. DSDP, 81: Washington (U.S. Govt. Printing Office).

2 Addresses: (Desprairies, Bonnot-Courtois, Vernhet) Laboratoire de Géochimie des Roches Sédimentaires, Université de Paris-Sud., Bât. 504, 91405 Orsay Cedex, France; (Jehanno) Centre des Faibles Radioactivités, CEA-CNRS, 91190 Gif-sur-Yvette, France; (Joron) Laboratoire P. Süe, CNRS-CEN Saclay, B.P. 2, 91190 Gif-sur-Yvette, France.
}

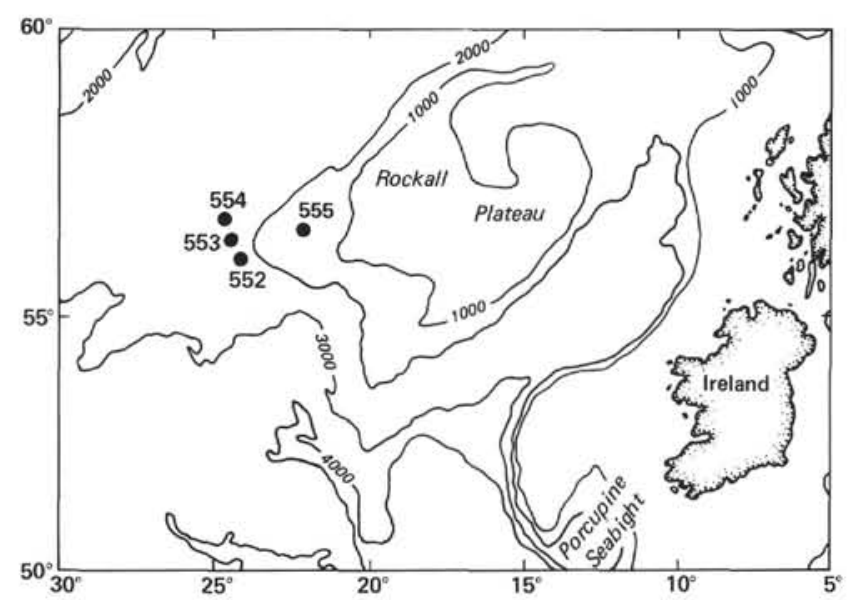

Figure 1. Location of DSDP Leg 81 sites.

Instrumental neutron activation analysis was used for the determination of trace elements in some selected samples (Chayla et al., 1973). The rare earth elements (REE) were measured by chemical neutron activation; details of the chemical separation after irradiation are described in Treuil et al. (1973). The countings were done using high-resolution Geli detectors. The analytical error for each individual measurement is about $10 \%$.

\section{SITE 552}

Hole 552 was drilled at $2311 \mathrm{~m}$ water depth on the southwest margin of the Rockall Plateau. An 8-m-thick single-flow basaltic sequence was encountered between 282.65 and $290.60 \mathrm{~m}$ sub-bottom, below early Eocene diatomaceous oozes.

This phyric basalt contains many vesicles which are equally dispersed in the whole sequence and sparse cracks. The groundmass is almost completely altered: smectites are well developed and have a mineralogical and chemical composition of Fe-rich saponites (Table 1, Fig. 2). Vesicles are filled with the same type of clay mineral.

The coating of the cracks is rimmed by Fe-rich saponite (Table 1) but the internal crack's filling contains 
Table 1. SEM/EDAX chemical analyses of iron-rich saponites and zeolites in basalt from Site 552 (in wt.\%).

\begin{tabular}{|c|c|c|c|c|c|c|c|}
\hline \multirow[b]{2}{*}{ Oxide } & \multicolumn{2}{|c|}{$\begin{array}{c}\text { Sample } \\
22-1 \text {, } \\
22-24 \mathrm{~cm}\end{array}$} & \multicolumn{5}{|c|}{$\begin{array}{c}\text { Sample } \\
22-1, \\
126-130 \mathrm{~cm}\end{array}$} \\
\hline & 1 & $2 a$ & $2 a$ & $2 b$ & $2 c$ & 3 & 4 \\
\hline $\mathrm{Na}_{2} \mathrm{O}$ & 2.6 & 0.7 & 0.9 & 0.6 & - & 14.3 & 8.4 \\
\hline $\mathrm{MgO}$ & 9.3 & 16.4 & 17.3 & 17.9 & 20 & - & - \\
\hline $\mathrm{Al}_{2} \mathrm{O}_{3}$ & 12.1 & 5.1 & 11 & 12.6 & 9.4 & 23 & 24.7 \\
\hline $\mathrm{SiO}_{2}$ & 48.7 & 53.5 & 48.6 & 39.7 & 47.8 & 62.7 & 60.3 \\
\hline $\mathrm{K}_{2} \mathrm{O}$ & 0.1 & 0.1 & - & - & - & - & - \\
\hline $\mathrm{CaO}$ & 4.3 & 1.3 & 3.1 & 1.3 & 3 & - & 6.3 \\
\hline $\mathrm{TiO}_{2}$ & 3.7 & 0.1 & - & - & - & - & - \\
\hline $\mathrm{Fe}_{2} \mathrm{O}_{3}$ & 19 & 22.8 & 19.1 & 27.9 & 19.8 & - & 0.3 \\
\hline $\mathrm{MnO}$ & 0.2 & - & - & - & - & - & - \\
\hline
\end{tabular}

Note: 1 = bulk rock analysis, 2 = iron-rich saponite from altered groundmass (a), infilling vesicles (b), and cracks (c), $3=$ analcite, $4=$ chabazite,$-=$ not detected.

white material composed of scarce calcite and often a mixing of zeolites (analcite and chabazite) (Table 1).

The saponite formation from the basaltic groundmass implies a supply of magnesium and a correlative loss of $\mathrm{Ca}, \mathrm{Na}, \mathrm{Si}$, and $\mathrm{Al}$. These elements could participate in the crystallization of analcite and chabazite, found along with the Fe-rich saponite. The mineralogical assemblage saponite-analcite often occurs in "medium" temperature alteration, for example, $70-90^{\circ} \mathrm{C}$ for one paragenesis analcite-chabazite described in the Iceland geothermal area (Kristmanndottir and Tomasson, 1978). More- over, the minerals require reducing conditions which are supported by the occurrence of pyrite in the samples studied here.

The sediments overlying the basalt are composed of brown diatomaceous ooze. The $<2 \mu$ m clay fraction extracted from this diatomaceous ooze has usual concentrations of iron $\left(\mathrm{Fe}_{2} \mathrm{O}_{3}, 12.82 \%\right)$ and transition elements (Mn, $153 \mathrm{ppm}$; $\mathrm{Co}+\mathrm{Cu}+\mathrm{Ni}, 130 \mathrm{ppm}$ ), similar to those commonly found in pelagic siliceous sediments. The mineralogical study reveals that the clay fraction is composed of an $\mathrm{Fe}-\mathrm{Mg}$-rich smectite (mixing of nontronite and saponite), associated with opal-CT (recrystallization of biogenic silica) and $\mathrm{Si}-\mathrm{Na}$-rich zeolite (mordenite). These smectites are probably linked with the presence of volcanic glass at this level and are probably authigenic. The $\mathrm{Mg}$-smectite percentage increases close to the basalt and may be related to the observed $\mathrm{Mg}$ sink of interstitial water (Shipboard Scientific Party, 1982).

The basalt was probably erupted in a shallow-water environment, as pillow lava. It was suggested that the oxidation was related to the basaltic extrusion into the marine environment (Shipboard Scientific Party, 1982), but it seems likely that the development of authigenic $\mathrm{Fe}-\mathrm{Mg}$ smectites in the oxidized zone of the pelagic sedimentation took place through diagenetic processes, without obvious connection with the more reducing alteration mechanisms prevailing in the underlying basalt.

\section{SITE 553}

Hole 553 was drilled at $2339 \mathrm{~m}$ water depth, and located $7.3 \mathrm{~km} \mathrm{SW}$ of Hole 552 (Fig 1). A 183-m-thick ba-

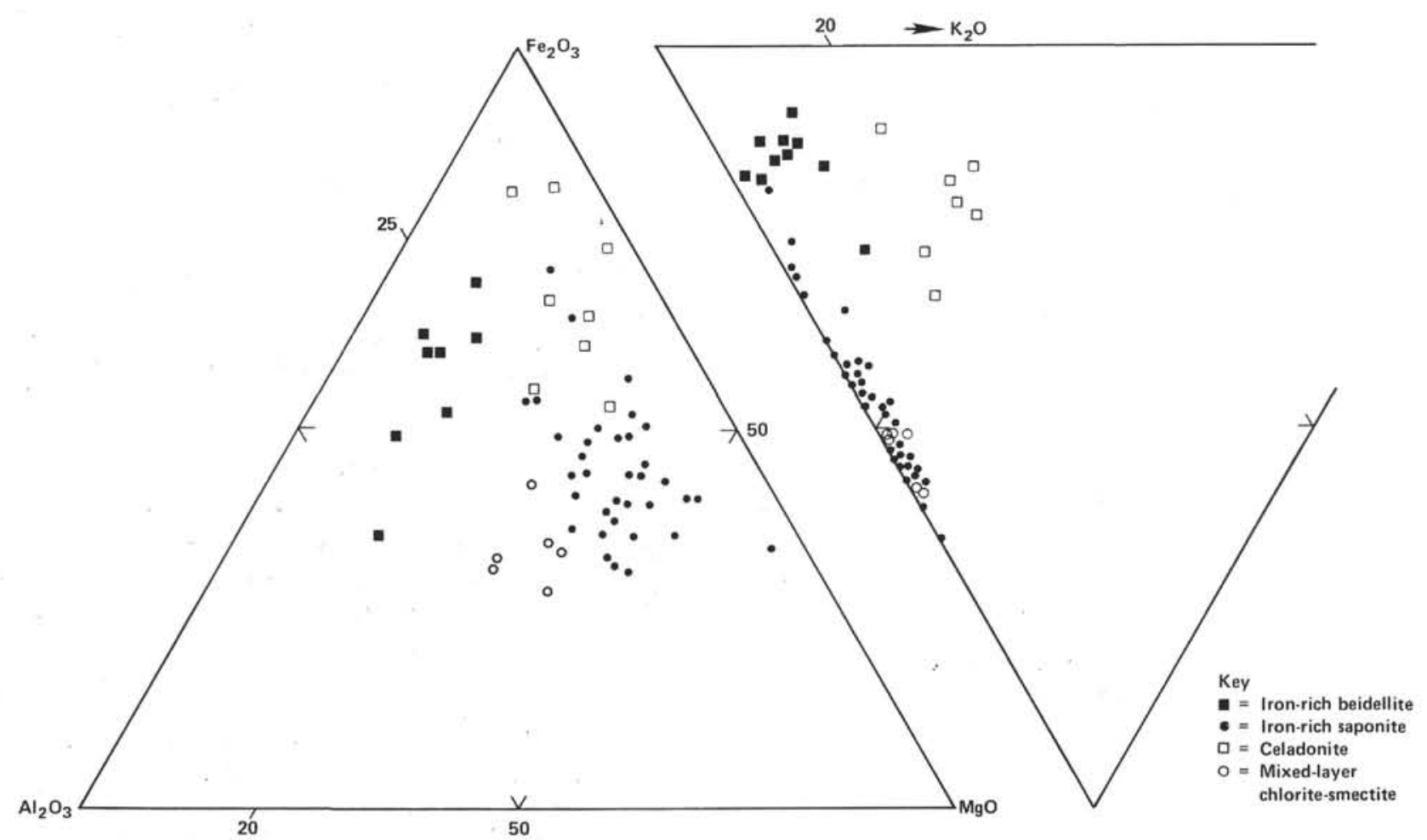

Figure 2. $\mathrm{Al}_{2} \mathrm{O}_{3}-\mathrm{Fe}_{2} \mathrm{O}_{3}-\mathrm{MgO}$ and $\mathrm{MgO}-\mathrm{Fe}_{2} \mathrm{O}_{3}-\mathrm{K}_{2} \mathrm{O}$ ternary diagrams showing the chemical composition of authigenic clay minerals found in alteration products from Leg 81 basalts. 
saltic sequence was recovered from 499 to $682 \mathrm{~m}$ below seafloor. The sequence is overlain by early Eocene sediments, and late Paleocene sediments are interbedded within the basaltic units. Three units were defined according to their physical and magnetic properties, not on the basis of petrographical differences. At least 27 basaltic flows were recognized and are separated by badly recovered volcaniclastic material (tuffs and breccias). Logging data also suggest the occurrence of sediments (terrigenous?) interbedded in the flows, but there is no direct evidence of this fact.

A typical sequence can be described as follows:

1. Vitric tuff without matrix, rarely lithic, sometimes showing a graded bedding. The top is always reddened and becomes progressively blacker toward the lower part of the tuffs.

2. Volcanic breccias represent the scoriaceous top of the underlying basalt. They are composed of large angular or slightly rounded fragments of reddened vesicular basalt. The clasts are fractured, show corrosion and fractures, and are cemented by reddened clay material. The red color decreases toward the lower part of the breccias, and an intermediate zone exists with the underlying basalt in the form of penetration of the breccias within the fractured surface of the basaltic flow.

3. The basaltic flows present a vesicular structure at the top of a massive and foliated one toward the central part of the flows. The vesicle's proportion increases at the base of the flows, which often exhibits chilled margins.

The mineralogical and chemical composition of the alteration products fluctuates from the central part of the flows to the volcaniclastic materials.

\section{Alteration of the Basaltic Flow}

The groundmass from the central parts of the flows is deeply altered to trioctahedral smectites (Fe-rich saponite) (Table 2, Fig. 2).

These clay minerals also fill the cracks and veins. The vesicular zones occurring at the top and the base of the flows contain two types of secondary minerals.

1. At the base, the vesicles are filled with the same saponite (Plate 1, Fig. 1) as is found in the altered groundmass. Sometimes, a zonation occurs. From the rim to the core of the vesicles, the saponite changes from black (small quantities of pyrite are present) to light green; simultaneously, the $\mathrm{Al}$ content decreases and the $\mathrm{Mg} / \mathrm{Fe}$ ratio increases (Table 2).

2. At the top of the flows, the vesicles are filled either with the same smectites as at the base of the flows or with a mixture of black saponite and dark green celadonite. In this case, the saponite occurs on the rims of the vesicles and always precedes the celadonite, which often represents the last infilling products (Plate 1, Fig. 2). However, an ultimate saponite deposit sometimes appears in the central part of the vesicles. The saponite from the core of the vesicles has a lower $\mathrm{Al}$ content than that from the rim and its $\mathrm{Mg} / \mathrm{Fe}$ ratio is higher (Table 2). This chemical evolution is similar to that observed at the base of the basaltic flows. The scanning electron microscope (SEM) observation (Plate 1, Fig. 2) shows that the saponite is also present between the lath-shaped celadonites. So, the saponite is a primary infilling phase, and the celadonite is always the secondary stage superimposed on the first one. The celadonite percentage increases toward the scoriaceous top of the flows. Simultaneously, the groundmass begins to be reddened, and the phenomenon becomes important in the volcanic breccias overlying the flows.

\section{Alteration of the Volcanic Breccias and Tuffs}

Two types of alteration products were found within the volcanic breccias. The first type is represented by the same saponite-celadonite association infilling some vesicles and is similar to the underlying vesicular top of flows previously described. The second type corresponds to reddish minerals developed from the groundmass, a part of the vesicles, and the clay matrix. All the mineralogical and chemical analyses show that the reddish products are constituted by a poorly crystallized dioctahedral smectite (Fe-rich beidellite) (Fig. 2), sometimes associated with saponite, and hematite (Table 3).

These two alteration processes are coexisting within the breccias, but the reddish products are most developed in the upper part of the breccias.

The vitric tuff is altered to a similar Fe-rich beidellite associated with important quantities of iron oxyhydroxides (Table 3, Plate 1, Fig. 3). The glass has a vesicular structure, and a rim of saponite is located between the altered glass and the core of the vesicles, which is also

Table 2. SEM/EDAX chemical analyses of the basalt alteration products from Site 553 (in wt. $\%$ ).

\begin{tabular}{|c|c|c|c|c|c|c|c|c|c|c|c|c|c|c|c|c|}
\hline \multirow[b]{3}{*}{ Oxide } & \multicolumn{16}{|c|}{ Sample (interval in $\mathrm{cm}$ ) } \\
\hline & \multicolumn{2}{|c|}{$40-1,82-85$} & \multicolumn{2}{|c|}{$59-4,71-75$} & \multirow{2}{*}{$\begin{array}{c}51-1, \\
55 \\
3\end{array}$} & \multirow{2}{*}{$\begin{array}{r}\begin{array}{r}44-3, \\
42-46\end{array} \\
3\end{array}$} & \multicolumn{2}{|c|}{$38-2,60-63$} & \multicolumn{3}{|c|}{$54-3,60$} & \multicolumn{5}{|c|}{$45-2,64$} \\
\hline & 1 & 2 & 1 & 2 & & & $4 a$ & $4 \mathrm{~b}$ & $5 a$ & $5 b$ & Sc & $6 a$ & $6 b$ & $6 c$ & $6 d$ & $6 e$ \\
\hline $\mathrm{Na}_{2} \mathrm{O}$ & 2.7 & 0. & 1.3 & 0.3 & 3,1 & - & - & - & - & - & - & 1.2 & 0.9 & - & 0.8 & 1.5 \\
\hline $\mathrm{MgO}$ & 5.5 & 15.9 & 8.3 & 18.8 & 20.0 & 21.2 & 17.5 & 16.8 & 21.40 & 21.2 & 23.2 & 16.3 & 10.2 & 7.8 & 14.2 & 19.5 \\
\hline $\mathrm{Al}_{2} \mathrm{O}_{3}$ & 13.9 & 6 & 14.4 & 12 & 5.4 & 10.1 & 9.9 & 8 & 4.3 & 3.9 & 1.3 & 8.3 & 6.5 & 7.2 & 6.7 & 7.1 \\
\hline $\mathrm{SiO}_{2}$ & 53.4 & 54.6 & 49.7 & 43 & 51.5 & 53.5 & 49.2 & 48.4 & 54 & 56 & 62.1 & 49.4 & 54.6 & 57.3 & 52.1 & 51.5 \\
\hline $\mathrm{K}_{2} \mathrm{O}^{\circ}$ & 0.1 & 0.5 & - & - & - & 0.1 & - & - & - & - & - & 0.4 & 6.1 & 8.7 & 3.3 & - \\
\hline $\mathrm{CaO}$ & 8.9 & 1.9 & 12.2 & 1.3 & 1.2 & 1.1 & 1.8 & 2.4 & 2.3 & 1.5 & 0.9 & 1.7 & 0.6 & 0.1 & 0.9 & 0.1 \\
\hline $\mathrm{TiO}_{2}$ & 1.4 & - & 1.0 & 0.3 & - & - & - & - & - & - & - & - & - & - & - & - \\
\hline $\mathrm{Fe}_{2} \mathrm{O}_{3}$ & 13.9 & 20.6 & 12.8 & 24.3 & 18.9 & 14.0 & 21.7 & 24.3 & 18.0 & 17.4 & 12.5 & 22.5 & 21.2 & 18.7 & 21.9 & 20.3 \\
\hline $\mathrm{MnO}$ & 0.2 & - & 0.3 & - & - & - & - & - & - & - & - & - & - & - & - & - \\
\hline
\end{tabular}

Note: 1-2-3 = massive central part of the basalt-bulk rock analysis (1), iron-rich saponite from the altered groundmass (2), and infilling cracks (3). 4-5-6 = Celadonite and iron-rich saponite infilling vesicles in vesicular basalt. From rim to core: black saponite (4a-4b); black (5a), dusky green (5b), light green saponite ( $4 a-4 b)$; black (Sa), dusky green ( $5 b$ ), light green saponite ( $5 c$ ); black saponite (6a), black saponite and dusky green celadonite $(6 \mathrm{~b})$, light green celadonite $(6 \mathrm{c})$, black saponite and dusky green celadonite $(6 \mathrm{~d})$, brown saponite $(6 \mathrm{e}) .-=$ no
detected. 
Table 3. SEM/EDAX chemical analyses of the basalt alteration products from Site 553 (in wt. \%).

\begin{tabular}{|c|c|c|c|c|c|c|c|c|c|c|c|c|c|c|}
\hline \multirow[b]{2}{*}{ Oxide } & \multicolumn{4}{|c|}{ Sample 49-6, 97-99 cm } & \multicolumn{3}{|c|}{$\begin{array}{c}\text { Sample } 50-3 \text {, } \\
60-62 \mathrm{~cm}\end{array}$} & \multicolumn{3}{|c|}{$\begin{array}{c}\text { Sample } 49-6 \text {, } \\
97-99 \mathrm{~cm}\end{array}$} & \multicolumn{4}{|c|}{ Sample $45-1,35-38 \mathrm{~cm}$} \\
\hline & 1 & 2 & 3 & 4 & $5 \mathrm{a}$ & $5 \mathrm{~b}$ & $5 \mathrm{c}$ & 6 & 7 & 7 & $8 \mathrm{a}$ & $8 \mathrm{~b}$ & $8 \mathrm{c}$ & $8 d$ \\
\hline $1 \mathrm{gO}$ & 10.0 & 8.0 & 20.6 & 16.1 & 19.3 & 6.1 & 22.5 & 7.5 & 16.4 & 20.6 & 5.1 & 16.3 & 18.3 & 4.9 \\
\hline $\mathrm{l}_{2} \mathrm{O}_{3}$ & 14.2 & 15.9 & 11.0 & 13.2 & 8.2 & 4.2 & 6.4 & 14.3 & 10.8 & 8.6 & 9.3 & 2.8 & 6.5 & 15.6 \\
\hline $\mathrm{SiO}_{2}$ & 54.8 & 62.5 & 51.3 & 55.3 & 51.9 & 58.9 & 54 & 62.3 & 54.2 & 52.2 & 50.3 & 32.8 & 49 & 64.2 \\
\hline $\mathrm{K}_{2} \mathrm{O}$ & 0.6 & 1.9 & 0.1 & 0.4 & - & 10.2 & - & 1.9 & 0.4 & - & 1.6 & 0.1 & 0.1 & 1.8 \\
\hline $\mathrm{CaO}$ & 2.8 & 1.7 & 1.8 & 2.8 & 2.4 & - & 1.0 & 2.4 & 2.3 & 2.2 & 1.6 & 1.8 & 2.4 & 1.6 \\
\hline $\mathrm{TiO}$ & 0.3 & - & - & - & - & - & - & - & - & - & 0.6 & 0.7 & - & 0.3 \\
\hline $\mathrm{Fe}_{2} \mathrm{O}_{3}$ & 17.3 & 10.0 & 15.2 & 12.2 & 18.2 & 20.6 & 16.1 & 11.6 & 15.9 & 16.4 & 31.5 & 45.5 & 23.7 & 11.6 \\
\hline
\end{tabular}

filled with Fe-rich beidellite. In contrast to the breccias the smectites from the core of the vesicles do not present all the chemical compositions intermediate between saponite and beidellite.

\section{Discussion}

In order to understand the occurrence of the smectite-celadonite assemblage, two types of complementary studies were conducted on the purest separated minerals. Oxygen isotopes were measured on two samples located at the top of the vesicular basalt and $\delta^{18} \mathrm{O}$ values are given in Table 4. The first sample (Sample 553-58-2, $34 \mathrm{~cm}$; Table 5) is a saponite extracted from a vein and gives a temperature of about $90^{\circ} \mathrm{C}$. The second sample (Sample 553-39-2, $38 \mathrm{~cm}$; Table 5) is a celadonite extracted from a vesicle and gives a temperature of about $60^{\circ} \mathrm{C}$ (Escande, 1983). However, these data are maximum temperatures without correction for iron content (Scheidegger and Stakes, 1977; Seyfried et al., 1978).

Hygromagmaphile and rare-earth element analyses were performed on separated saponite and celadonite, extracted from vesicles and cracks at different levels in the vesicular basalt (Table 5). The two clay minerals have similar characteristics:

1. Very low REE contents (5-20 ppm) and U (always below the detection limit), Th, and Ta contents (Table 6 ) equal to those found in the fresh basalt (Joron et al., this volume);

2. Chondritic-normalized REE patterns (Fig. 3) showing a strong depletion in lightest REE similar to those observed in the fresh basaltic samples from the same hole (Joron et al, this volume);

3. An enrichment in the heaviest REE is especially pronounced in the saponite.

Table $4 \cdot \delta^{18} \mathrm{O}$ values from iron-rich saponite and celadonite from Hole 553A.

\begin{tabular}{|c|c|c|c|c|}
\hline Samples & $\begin{array}{c}\delta^{18} \mathrm{O} \text { sample vs. } \\
\text { SMOW (\%o) }\end{array}$ & 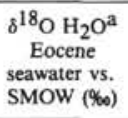 & $\begin{array}{c}10^{3} \ln \alpha \\
\text { (sample }-\mathrm{H}_{2} \mathrm{O} \text { ) (\%o) }\end{array}$ & $\mathrm{T}\left({ }^{\circ} \mathrm{C}\right)^{\mathrm{b}}$ \\
\hline $\begin{array}{l}\text { Iron-rich saponite, } \\
\text { Sample 58-2, } \\
34 \mathrm{~cm}\end{array}$ & +18.49 & & +19.43 & 95 \\
\hline $\begin{array}{l}\text { Celadonite, } \\
\text { Sample } 39-2 \text {, } \\
38 \mathrm{~cm}\end{array}$ & +17.11 & -1.1 & +18.20 & 55 \\
\hline
\end{tabular}

These geochemical characteristics have already been observed in hydrothermal deposits from the FAMOUS area or from the Galapagos hydrothermal mounds (Bonnot-Courtois, 1981). The very low trace metal content seems to be typical of this type of deposit but was recognized before only for iron-montmorillonite from the Red Sea (Courtois and Treuil, 1977) or for nontronite (Hoffert et al., 1980). This is the first observation of this kind for $\mathrm{Mg}$ smectites. Very pure celadonite, studied in Cyprus (Courtois and Desprairies, 1978), also shows very low REE content (1 ppm) and a REE distribution curve similar to those of celadonites from Hole 553. Compared to the fresh basalt, the smectite and celadonite are relatively enriched in transition elements $(\mathrm{Fe}, \mathrm{Co}$, $\mathrm{Ni}$ ) while other trace elements have similar concentrations. Saponites are also richer in $\mathrm{Co}$ and $\mathrm{Ni}$ than celadonites (Table 6). The chemical composition of these clay minerals especially reflects the chemical composition of the basalt, but some elements can be completely $(\mathrm{Na}, \mathrm{K})$ or partly ( $\mathrm{Mg}$ and transition elements) carried with fluids.

Another problem is the presence of weak $\mathrm{Ce}$ anomalies in REE patterns (Fig. 3). One must be careful because of the very low REE concentrations and consequently important analytical errors. However, if these anomalies have a significance, it is interesting to notice that the $\mathrm{Ce}$ anomalies go the same way (positive or negative) for saponites and celadonites associated in the same vesicles. The occurrence of $\mathrm{Ce}$ anomalies is often related to varying redox conditions of the environment. Here, the $\mathrm{Ce}$ anomalies are positive in the samples located at the top of the flows where we have observed the development of oxidizing conditions; obviously, more data are necessary to answer this question. Nevertheless, saponites and celadonites have quite similar chemical compositions, except for the very exchangable cations such as $\mathrm{Mg}, \mathrm{Na}$, and $\mathrm{K}$.

These facts, correlated with the SEM observations and trace-element behavior, suggest that the celadonite comes from the transformation of the saponite. The two different paleotemperatures observed are in agreement with the primary formation of the saponite.

In contrast to the hydrothermal alteration products described above, which occur in the whole basaltic sequence, the reddened levels are only located at the top of the flows, in the breccias and in the tuffs. The association of Fe-rich beidellite and iron oxyhydroxides is 
Table 5. Chemical analyses (wt.\%) and structural formulas of iron-rich saponite and celadonite in basalt from Site 553.

\begin{tabular}{|c|c|c|c|c|c|c|c|c|c|c|}
\hline & \multirow[b]{6}{*}{ Oxide } & \multicolumn{9}{|c|}{ Vesicular basalt section } \\
\hline & & \multicolumn{4}{|c|}{ Top } & \multicolumn{3}{|c|}{ Medium part } & \multicolumn{2}{|c|}{ Lower part } \\
\hline & & \multicolumn{7}{|c|}{ Sample (interval in $\mathrm{cm}$ ) } & & \\
\hline & & \multirow{3}{*}{$\frac{\frac{58-2,34}{\text { Vein }}}{\text { Sap. }}$} & \multirow{3}{*}{$\frac{\frac{39-2,38}{\text { Vesicle }}}{\text { Cel. }}$} & \multirow{2}{*}{\multicolumn{2}{|c|}{$\frac{40-1,15-18}{\text { Vesicle }}$}} & \multirow{2}{*}{\multicolumn{2}{|c|}{$\begin{array}{c}47-1,33-35 \\
\text { Vesicle }\end{array}$}} & \multirow{3}{*}{$\begin{array}{l}\begin{array}{c}47-1, \\
87-89\end{array} \\
\frac{\text { Crack }}{\text { Cel. }}\end{array}$} & \multicolumn{2}{|c|}{$\frac{41-3,3-6}{\text { Yesicle }}$} \\
\hline & & & & & & & & & & \\
\hline & & & & Sap. & Cel. & Sap. & Cel. & & Sap. & Cel \\
\hline & $\mathrm{Na}_{2} \mathrm{O}$ & 2.6 & - & 4.1 & - & 7.8 & 2.1 & - & 6.5 & 0.5 \\
\hline & $\mathrm{MgO}$ & 19.7 & 8.4 & 14.4 & 8.0 & 16.1 & 9.7 & 7.4 & 16.6 & 12.5 \\
\hline & $\mathrm{Al}_{2} \mathrm{O}_{3}$ & 6.4 & 3.5 & 6.7 & 7.5 & 5.3 & 7.3 & 0.7 & 5.4 & 4.7 \\
\hline & $\mathrm{SiO}_{2}$ & 52.2 & 56.9 & 55.4 & 58.9 & 51.4 & 54.8 & 59.0 & 52.1 & 56.3 \\
\hline & $\mathrm{K}_{2} \mathrm{O}$ & 0.3 & 9.3 & 2.1 & 8.1 & 0.7 & 5.7 & 9.6 & 0.8 & 5.7 \\
\hline & $\mathrm{CaO}$ & 1.5 & - & 1.0 & 1.2 & 1.6 & 2.1 & 0.2 & 0.5 & 0.7 \\
\hline & $\mathrm{TiO}_{2}$ & - & - & - & 0.2 & - & - & - & - & 0.1 \\
\hline & $\mathrm{Fe}_{2} \mathrm{O}_{3}$ & 9.3 & 15.8 & $16.3^{\mathrm{a}}$ & $16.1^{\mathrm{a}}$ & $17.1^{\mathrm{a}}$ & $18.3^{\mathrm{a}}$ & $23.1^{\mathrm{a}}$ & $18.1^{\mathrm{a}}$ & $19.5^{\mathrm{a}}$ \\
\hline & $\mathrm{FeO}^{\circ}$ & 8.0 & 6.1 & - & - & - & - & - & - & - \\
\hline & Si & 3.44 & 3.88 & 3.61 & 3.87 & 3.42 & 3.64 & 3.99 & 3.45 & 3.72 \\
\hline $\begin{array}{l}\text { letra- } \\
\text { hedral }\end{array}$ & $\mathrm{Al}$ & 0.50 & 0.12 & 0.39 & 0.13 & 0.42 & 0.36 & 0.01 & 0.42 & 0.28 \\
\hline & $\mathrm{Fe}^{3+}$ & 0.06 & - & - & - & 0.16 & - & - & 0.13 & - \\
\hline & $\mathrm{Al}_{3+}$ & - & 0.16 & 0.13 & 0.45 & - & 0.21 & 0.04 & - & 0.08 \\
\hline Octa- & $\mathrm{Fe}^{3+}$ & 0.40 & 0.81 & $0.80^{\mathrm{a}}$ & $0.79^{\mathrm{a}}$ & $0.70^{\mathrm{a}}$ & $0.91^{\mathrm{a}}$ & $1.18^{\mathrm{a}}$ & $0.77^{\mathrm{a}}$ & $0.97^{\mathrm{a}}$ \\
\hline hedral & $\mathrm{Fe}^{2+}$ & 0.44 & 0.35 & - & - & - & - & - & - & - \\
\hline & $\mathrm{Mg}$ & 1.94 & 0.85 & 1.40 & 0.78 & 1.60 & 0.97 & 0.74 & 1.64 & 1.23 \\
\hline & K & 0.11 & 0.81 & 0.17 & 0.67 & 0.06 & 0.49 & 0.83 & 0.06 & 0.48 \\
\hline $\begin{array}{l}\text { Inter- } \\
\text { layer }\end{array}$ & $\mathrm{Na}$ & 0.33 & - & 0.52 & - & 1.00 & 0.26 & - & 0.83 & 0.06 \\
\hline & $\mathrm{Ca}$ & 0.12 & - & 0.06 & 0.09 & 0.11 & 0.15 & 0.02 & 0.03 & 0.06 \\
\hline
\end{tabular}

Table 6. Concentration of REE and other trace elements (ppm).

\begin{tabular}{|c|c|c|c|c|c|c|c|c|}
\hline \multirow[b]{3}{*}{ Oxide } & \multicolumn{8}{|c|}{ Sample (interval in $\mathrm{cm}$ ) } \\
\hline & \multirow{2}{*}{$\frac{58-2,34}{\text { Sap. }}$} & \multicolumn{2}{|c|}{$40-1,15-18$} & \multicolumn{2}{|c|}{$47-1,33-35$} & \multirow{2}{*}{$\begin{array}{l}\begin{array}{l}47-1, \\
87-89\end{array} \\
\text { Cel. }\end{array}$} & \multicolumn{2}{|c|}{$41-3,3-6$} \\
\hline & & Sap. & Cel. & Sap. & Cel. & & Sap. & Cel. \\
\hline Th & - & 0.075 & 0.11 & 0.047 & 0.11 & - & 0.057 & 0.070 \\
\hline $\mathrm{Hf}$ & - & 1.50 & 2.2 & 0.4 & 1.2 & - & 0.67 & 1.46 \\
\hline Ta & - & 0.028 & 0.066 & 0.018 & 0.024 & - & 0.008 & 0.025 \\
\hline Cs & $=$ & 0.20 & 0.20 & 0.09 & 0.20 & $=$ & 0.21 & 0.10 \\
\hline $\mathrm{Rb}$ & - & 28.4 & 67.5 & 10.6 & 50.4 & - & 15.9 & 119 \\
\hline $\mathrm{Cr}$ & - & 214 & 117 & 6 & 29 & - & 26 & n.d. \\
\hline Co & - & 65.5 & 51.1 & 84.3 & 67.8 & - & 93.1 & 30.0 \\
\hline $\mathrm{Ni}$ & - & 106 & 72 & 109 & 90 & - & 124 & 32 \\
\hline Sc & - & 40 & 89 & 6.3 & 36.4 & - & 19.1 & 18.0 \\
\hline $\mathrm{La}$ & 0.32 & 1.9 & 2.5 & 1.24 & 2.3 & 0.55 & 0.83 & 1.44 \\
\hline $\mathrm{Ce}$ & 1.3 & 7.6 & 11.2 & 3.4 & 5.7 & 0.77 & 1.4 & 4.6 \\
\hline $\mathrm{Nd}$ & $<1$ & - & - & - & - & 0.70 & - & - \\
\hline $\mathrm{Sm}$ & 0.35 & 1.78 & n.d. & $\overline{0.69}$. & 2.67 & 0.21 & $\overline{0.60}$ & $\overline{1.70}$ \\
\hline $\mathrm{Eu}$ & 0.15 & 0.77 & 0.94 & 0.24 & 1.07 & 0.09 & 0.20 & 0.74 \\
\hline $\mathrm{Tb}$ & 0.13 & 0.60 & 0.75 & 0.40 & 0.86 & 0.07 & 0.22 & 0.55 \\
\hline $\mathrm{Yb}$ & 0.90 & 4.7 & 5.1 & 4.3 & 4.5 & 0.35 & 1.67 & 3.5 \\
\hline $\mathrm{Lu}$ & 0.18 & - & - & - & - & 0.06 & - & \\
\hline IREE & 4 & 17 & 20 & 10 & 17 & 3 & 5 & 12 \\
\hline
\end{tabular}

Note: Sample numbers are the same as in Table 5. n.d. $=$ not detected; $-=$ not analyzed.

present in the reddened levels, and these minerals are often found in submarine alteration (palagonitization).

However, the beidellites are not enriched in potassium, and the occurrence of hematite is unusual in typical palagonites (Honnorez, 1980). Moreover, the flows have a glassy basal margin and a scoriaceous top where the volcanic fragments have not been reworked. The tuffs present characteristics more similar to ash fall than to hyaloclastites. These factors are in agreement with subaerial extrusion of basalts (Shipboard Scientific Party, 1982). If the alteration took place in a subaerial environment, the weathering did not induce the formation of a paleosoil, for the base of the flows is sometimes reddened. The process could be an oxidizing alteration between successive flows which overlie sediments(?), tuffs, and breccias with high water content. This interpreta- tion was already suggested for some red intrabasaltic levels in Iceland (Person, 1976).

The relationship between hydrothermal and subaerial alteration is still in question. The widespread occurrence of saponite and celadonite in the basaltic sequence contrasts with the local occurrence of the beidellites in the reddened levels. In some vesicles of the reddish zone, saponite is still present and sometimes precedes the beidellite crystallization. So the subaerial weathering would appear after the hydrothermal alteration.

\section{SITE 554}

Hole 554 was drilled at $2584 \mathrm{~m}$ water depth on the extreme western margin of the Rockall Plateau (Fig. 1) on the "Outer High" separating the zone of the dipping reflectors (Sites 552, 553 and 555) from the adjacent oceanic crust. Unit V of Hole 554 consists of 82.25 -m-thick submarine basalt (six flows), interlayered with volcanogenic sandstones and conglomerates, recovered between 126.75 and $209 \mathrm{~m}$ below seafloor. In the central zone of the flows, the gray-colored, vitric groundmass is not altered. The color of the groundmass becomes dark brown, green, and yellowish brown along the cracked top and base of the flows. These colors and their zonation look like the low-temperature submarine alteration of the palagonite type (Honnorez, 1980; Noack, 1981). The number of vesicles decreases toward the central zone of the flows. In most cases, the vesicles are empty or simply lined with green clay.

Two types of cracks occur. Most of them, $2 \mathrm{~mm}$ in size, are located in the central zone of the flows and are successively filled with black clay, green clay, and finally calcite. The other types of cracks are wider (up to $2 \mathrm{~cm}$ ) and occur at the top of the flows. They are filled with a breccia composed of angular volcanic glass fragments 


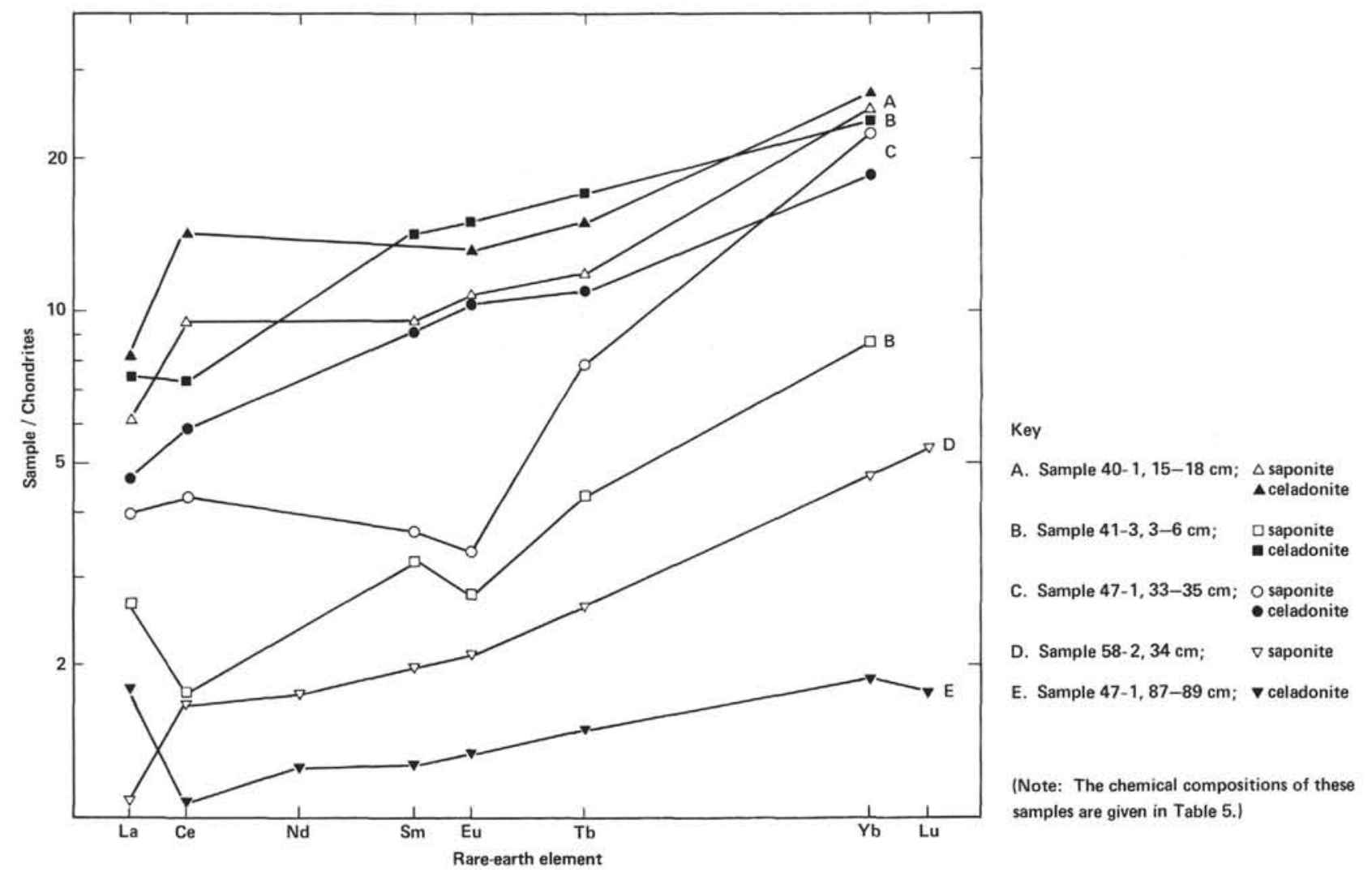

Figure 3. Chondritic-normalized REE patterns of smectites and celadonites from Hole 553.

and basaltic clasts, deeply palagonitized, and cemented with sparitic or micritic calcite.

This volcanic breccia, in which some elements are possibly hyaloclastites, also overlies the top of the flows. All the intermediate stages exist between the breccia and the volcanogenic conglomerates and sandstones interbedded in the flows. These materials show the same type of alteration (palagonitization) as in the breccia and at the top of the flows. These facts suggest an in situ reworking in a high-energy littoral environment (Shipboard Scientific Party, 1982).

Alteration products were studied in the three volcanic facies: flows, breccias, and conglomerates.

\section{Alteration of the Basaltic Flows}

In the central zone of the flows (Sample 554-14-1, $75-77 \mathrm{~cm}$ ), the mineralogical and chemical analyses (Table 7) show that the black and green material infilling the cracks is respectively formed by smectites (Fe-rich saponite type) and celadonite (Fig. 2). This last one also lined the vesicles. It will be noticed that the celadonite from Hole 554 is a very Al-poor celadonite, much more than the same mineral analyzed in Hole 553.

The top and the base of the flows (Sample 554-12-1, $5-8 \mathrm{~cm}$ ) show chilled margins. There are no microliths in the groundmass but phenocrysts of plagioclase, cli-

Table 7. SEM/EDAX chemical analyses of the basalt alteration products from Site 554 (wt.\%).

\begin{tabular}{|c|c|c|c|c|c|c|c|c|c|c|}
\hline \multirow[b]{3}{*}{ Oxide } & \multicolumn{3}{|c|}{$\begin{array}{c}\text { Sample 14-1, } \\
75-77 \mathrm{~cm}\end{array}$} & \multicolumn{5}{|c|}{ Sample $12-1,5-8 \mathrm{~cm}$} & \multirow{3}{*}{$\begin{array}{c}\begin{array}{c}\text { Sample } 7-41, \\
66-70 \mathrm{~cm}\end{array} \\
\begin{array}{c}\text { Volcanic } \\
\text { conglom- } \\
\text { erate }\end{array} \\
6 \mathrm{c}\end{array}$} & \multirow{3}{*}{$\begin{array}{c}\begin{array}{c}\text { Sample } 7-4 \\
82-85 \mathrm{~cm}\end{array} \\
\begin{array}{c}\text { Volcanic } \\
\text { sand }\end{array} \\
\text { 6d }\end{array}$} \\
\hline & \multicolumn{3}{|c|}{ Core basalt } & \multicolumn{2}{|c|}{ Top basalt } & \multicolumn{2}{|c|}{$\begin{array}{l}\text { Chilled } \\
\text { margin }\end{array}$} & \multirow{2}{*}{$\frac{\begin{array}{c}\text { Volcanic } \\
\text { breccia }\end{array}}{6 \mathrm{~b}}$} & & \\
\hline & 1 & 2 & 3 & $4 a$ & $4 b$ & 5 & $6 a$ & & & \\
\hline $\mathrm{Na}_{2} \mathrm{O}$ & 1.70 & 1.0 & 0.3 & 0.4 & 3.7 & 0.4 & 0.4 & - & 0.7 & - \\
\hline $\mathrm{MgO}$ & 7.50 & 14.5 & 4.8 & 6.1 & 4.2 & 5.0 & 4.7 & 6.3 & 3.5 & 3.9 \\
\hline $\mathrm{Al}_{2} \mathrm{O}_{3}$ & 13.90 & 3.8 & 1.7 & 12,4 & 14.6 & 12.6 & 14.2 & 11.5 & 4.2 & 12.9 \\
\hline $\mathrm{SiO}_{2}$ & 50.4 & 52.4 & 55.5 & 48.2 & 48.2 & 49 & 44.8 & 46.7 & 52.3 & 47.2 \\
\hline $\mathrm{K}_{2} \mathrm{O}$ & 0.20 & 1.6 & 8.2 & 0.4 & 0.6 & 3.8 & 3.2 & 4.2 & 5.3 & 4.8 \\
\hline $\mathrm{CaO}$ & 11.60 & 1.6 & 0.3 & 10.4 & 9.3 & 1.0 & 1.3 & 0.7 & 1.0 & 0.6 \\
\hline $\mathrm{TiO}_{2}$ & 1.10 & 0.2 & - & 1.6 & 1.3 & 2 & 2.4 & 1.5 & 0.1 & 2.4 \\
\hline $\mathrm{Fe}_{2} \mathrm{O}_{3}$ & 13.4 & 24.9 & 29.2 & 20.5 & 18.1 & 26.2 & 29 & 29.1 & 32.9 & 28.2 \\
\hline $\mathrm{MnO}$ & 0.20 & - & - & - & - & - & - & - & - & - \\
\hline
\end{tabular}


nopyroxene, and olivine are still present. These two types of texture show different ways of alteration:

1. In the microlitic zone, the gray groundmass progressively turns red nearby the chilled margin. This oxidation does not lead to the transformation of glass to clay minerals; the chemical composition of the reddened groundmass is close to that of fresh glass, especially the $\mathrm{CaO}$ content (Table 7).

2 . In the glassy margin, the groundmass becomes green and yellowish brown and is almost completely altered in a dioctahedral smectite (Fe-rich beidellite). The $\mathrm{CaO}$ content decreases as the $\mathrm{K}_{2} \mathrm{O}$ concentration increases (Table 7). In the green facies, the clays have a massive texture and are poorly crystallized. In the yellowish brown facies, granules with fibrous texture appear in the clay matrix (variolitic zone, Juteau et al., 1980). The smectites are enriched in Fe and their X-ray diffraction patterns show better crystallinity than in the green facies.

\section{Alteration of the Volcanic Breccias (Sample 554-12-1, $58 \mathrm{~cm}$ ) and Conglomerates (Sample 554-7-4, 66-70 cm)}

The same type of palagonitization described above exists in the glass and volcanic fragments from breccias. The mineralogy and chemistry of alteration products are similar to those of the flows (Table 7).

So, these breccias can be considered hyaloclastites that formed at the same time as the extrusion of lavas but before both volcanic facies were palagonitized. The breccias' matrix is often composed of an assemblage of sparitic calcite and $\mathrm{Na}-\mathrm{K}$ phillipsite.

In conglomerates and sandstones, the clastic elements, more or less rounded, exhibit the same type of alteration as the breccias, which confirms the reworking.

\section{Discussion}

A geochemical balance, with constant $\mathrm{Fe}$ or $\mathrm{Ti}$, between the fresh rock and the altered glass from the flows and the breccias obviously shows a loss of $\mathrm{Ca}$ and $\mathrm{Na}$; $\mathrm{a}$ decrease of $\mathrm{Si}, \mathrm{Al}$, and $\mathrm{Mg}$; and an important $\mathrm{K}$ enrichment. This balance is characteristic of low-temperature alteration and is confirmed by the composition of authigenic smectites (Fe-rich beidellites) associated with phillipsite. The formation of this zeolite is related to the chemical elements lost during the glass hydrolysis, namely, $\mathrm{Si}, \mathrm{Na}$, and $\mathrm{Al}$.

In contrast, the saponite formation in the central zone of the flows is induced by a Mg enrichment which corresponds to another type of alteration. During experimental alteration, the $\mathrm{Mg}$ enrichment is observed above $70^{\circ} \mathrm{C}$, whereas the $\mathrm{K}$ enrichment occurs at lower temperatures (Mottl and Holland, 1978; Seyfried and Bischoff, 1979). The celadonite crystallization could occur below this temperature level with change from reducing conditions (saponite) to oxidizing ones (Seyfried et al., 1978). We have already recorded one example in Hole 553. In summary, the late process of palagonitization could be superimposed on previous saponite and celadonite formation. This hypothesis is supported by the singular occurrence of $\mathrm{K}$-rich nontronite in the palagonite. This nontronite may be the end result of the celadonite trans- formation (Sample 554-7-4, 82-85 cm, Table 7; analysis 6d).

\section{SITE 555}

Hole 555 was drilled at $1669 \mathrm{~m}$ water depth and was located some $160 \mathrm{~km}$ ENE of Hole 554A, between Hatton Bank and Edoras Bank. Basalts were recovered from 672 to $964 \mathrm{~m}$ below seafloor, and are interbedded with tuffs and lapilli tuffs associated with terrigenous sediments, which are composed of micaceous and feldspathic sand, silt, and mudstones. Sediments of mixed origin, such as sandy vitric tuffs, are also commonly present (Shipboard Scientific Party, 1981). Basaltic units are either single thick flows or single or composite pillow lavas.

We have studied the alteration products of the basaltic flows and tuffs and the interaction between basalt and terrigenous sediments.

\section{Alteration of the Basaltic Flows and Tuffs}

The groundmass is completely altered to saponites. In the central part of the flows, the chemical composition of these saponites changes with the depth of the basaltic units. The deepest basaltic unit studied (Sample 555-97-1, 34-38 cm) contains a saponite with a very high iron concentration, close to the composition of a nontronite (Table 8). As the depth diminishes in the basaltic sequence, the iron concentration of the saponite decreases and the shallowest basaltic unit studied (Sample 555-694, 88-92 cm) contains an Mg-enriched saponite (Table 8 ). This chemical evolution could be related to the varying basaltic texture, which is ophitic in the deepest part of the hole, becoming phyric in the upper part.

In the glassy margins of the flows, the smectites become Al-rich saponite. The vesicles are filled with the same clay minerals, but some cracks contain a mixedlayer chlorite-smectite (Table 8, Fig. 2).

The terrigenous clay fraction (illite, kaolinite, chlorite, and dioctahedral smectite) is always present within the tuffs. An authigenic trioctahedral smectite (saponite) also exists in these tuffs and is associated with chlorite in the vesicles (Plate 1, Fig. 4). This chlorite has a composition of a diabantite (Foster, 1962). The matrix of the clasts is composed of analcite (Table 8).

$\mathrm{The} \mathrm{La} / \mathrm{Yb}$ ratio of these tuffs is low and confirms the presence of basic volcanogenic material, but the Th/ Ta ratio of 6 is slightly higher than those of the basaltic flow ( $\mathrm{Th} / \mathrm{Ta} \cong 3$, Joron et al., this volume). The analysis of terrigenous mudstone located above the basaltic sequence (Sample 555-64-1, $48 \mathrm{~cm}$ ) gives higher $\mathrm{La} / \mathrm{Yb}$ and $\mathrm{Th} / \mathrm{Ta}$ ratios (13 and 12 , respectively). These terrigenous components are still present within the tuffs and do not allow the assertions that the "hyaloclastites" are genetically related to the basalt or that they correspond to pyroclastic products emitted from the rifted margins.

\section{Interaction between Basalt and Terrigenous Sediments}

The sediments are often baked near the basalt. The mineralogy changes from a detrital assemblage to a clay fraction only composed of saponite and of mixed-layer chlorite-smectite in contact with the basalt. The same 
Table 8. SEM/EDAX chemical analyses (wt.\%) of basalt and tuff alteration products from Site 555. Structural formulas of clay minerals.

\begin{tabular}{|c|c|c|c|c|c|c|c|c|c|c|c|c|c|c|c|c|c|c|}
\hline \multirow[b]{3}{*}{ Oxide } & \multicolumn{18}{|c|}{ Sample (interval in $\mathrm{cm}$ ) } \\
\hline & \multirow{2}{*}{$\begin{array}{c}69-4 \\
88-92 \\
\text { la }\end{array}$} & \multirow{2}{*}{$\begin{array}{c}90-3, \\
54-57 \\
1 \mathrm{~b}\end{array}$} & \multirow{2}{*}{$\begin{array}{c}97-1, \\
34-38 \\
\text { Ic }\end{array}$} & \multicolumn{2}{|c|}{$82-1,107-111$} & \multirow{2}{*}{$\begin{array}{l}\frac{90-1,}{40-42} \\
2 a\end{array}$} & \multicolumn{4}{|c|}{$91-1,55-60$} & \multirow{2}{*}{$\frac{\begin{array}{c}91-1, \\
129-133\end{array}}{2 e}$} & \multicolumn{2}{|c|}{$\begin{array}{c}93-2 \\
121-126\end{array}$} & \multicolumn{2}{|c|}{$93-3,3$} & \multicolumn{3}{|c|}{$92-1,29-35$} \\
\hline & & & & $2 b$ & $3 a$ & & $2 c$ & 20 & & $3 \mathrm{~b}$ & & $3 \mathrm{c}$ & $3 d$ & 4 & $2 \mathrm{f}$ & $5 \mathrm{a}$ & $5 b$ & 6 \\
\hline $\mathrm{Na}_{2} \mathrm{O}$ & 0.3 & 0.6 & 0.5 & 2.0 & - & 1.2 & - & - & & - & 3.7 & - & - & 3.8 & 3.8 & - & - & 12.7 \\
\hline $\mathrm{MgO}$ & 17.1 & 10.5 & 7.8 & 18.5 & 22.3 & 4.4 & 18.6 & 22. & & 20.3 & 16.5 & 14.3 & 15.4 & 20.2 & 21.2 & 19.6 & 18.9 & \\
\hline $\mathrm{Al}_{2} \mathrm{O}_{3}$ & 4.5 & 5.1 & 5.0 & 8.8 & 12 & 15.8 & 9.6 & 13. & & 11.7 & 12.1 & 13.6 & 13.6 & 16.5 & 13.5 & 21.4 & 20.7 & 23 \\
\hline $\mathrm{SiO}_{2}$ & 54.3 & 52 & 50.1 & 52 & 46.2 & 64.8 & 48.1 & 36. & & 37.8 & 49.6 & 37.6 & 35.5 & 38 & 45.2 & 38.7 & 39.9 & 64.3 \\
\hline $\mathrm{K}_{2} \mathrm{O}$ & 0.2 & 0.6 & 1.1 & & & 1.6 & 0.1 & - & & - & 0.8 & - & - & - & - & - & - & \\
\hline $\mathrm{CaO}$ & 1.4 & 2.1 & 3.1 & 1.6 & 2.3 & 1.4 & 3.3 & 1. & & 1.2 & 2.2 & 1.5 & 0.7 & 20.1 & 1.0 & 1.0 & 1.5 & \\
\hline $\mathrm{TiO}_{2}$ & 0.2 & 0.3 & - & & & 1.2 & 0.2 & - & & 0.3 & 0.3 & - & - & - & - & 0.7 & 0.8 & \\
\hline $\mathrm{Fe}_{2} \mathrm{O}_{3}$ & $21.9^{\mathrm{a}}$ & $28.6^{\mathrm{a}}$ & $31.8^{\mathrm{a}}$ & $17.1^{\mathrm{a}}$ & $17.2^{\mathrm{a}}$ & $9.6^{\mathrm{a}}$ & $20.0^{\mathrm{a}}$ & a $\quad 26$. & & $28.5^{\mathrm{a}}$ & $14.8^{\mathrm{a}}$ & $33.0^{\mathrm{a}}$ & $34.8^{\mathrm{a}}$ & $19.4^{\mathrm{a}}$ & $15.3^{\mathrm{a}}$ & & & \\
\hline $\mathrm{FeO}$ & & & & & & & & & & & & & & & & $18.2^{b}$ & $17.9^{\mathrm{b}}$ & \\
\hline \multirow[t]{2}{*}{$\mathrm{MnO}$} & 0.1 & 0.2 & 0.6 & & & & & & & & & & & & & 0.4 & 0.3 & \\
\hline & \multicolumn{3}{|c|}{ Tetrahedral } & \multicolumn{4}{|c|}{ Octahedral } & \multicolumn{4}{|c|}{ Interlayer } & & & & & & & \\
\hline Samples & $\mathrm{Si}$ & $\mathrm{Al}$ & $\mathrm{Fe}^{3+}$ & $\mathrm{Al}$ & $\mathrm{Fe}^{3+}$ & $\mathrm{Fe}^{2+}$ & $\overline{\mathrm{Mg}}$ & $\mathrm{Mg}$ & $\mathrm{K}$ & $\mathrm{Na}$ & $\overline{\mathrm{Ca}}$ & & & & & & & \\
\hline $2 a$ & 3.99 & 0.01 & & 1.14 & 0.44 & & 0.40 & & 0.13 & 0.14 & 0.09 & & & & & & & \\
\hline $1 \mathrm{a}$ & 3.54 & 0.34 & 0.12 & & 0.95 & & 1.57 & 0.10 & 0.01 & 0.04 & 1.10 & & & & & & & \\
\hline 1c & 3.42 & 0.40 & 0.18 & & 1.46 & & 0.79 & & 0.10 . & 0.60 & 0.23 & & & & & & & \\
\hline $2 c$ & 3.17 & 0.74 & 0.09 & & 0.90 & & 1.65 & 0.17 & 0.01 & & 0.24 & $11 \mathrm{ox}$. & & & & & & \\
\hline $2 d$ & 2.48 & 1.08 & 0.44 & & 0.91 & & 1.63 & 0.64 & & & 0.12 & & & & & & & \\
\hline 4 & 2.56 & 1.31 & 0.13 & & 0.85 & & 1.72 & 0.31 & & 0.49 & 0.16 & & & & & & & \\
\hline $5 a$ & 3.57 & 0.63 & & 1.57 & & 1.32 & 2.54 & & & & 0.10 & $14 \mathrm{ox}$. & & & & & & \\
\hline
\end{tabular}

Note: 1 = Mg saponite (1a) to Fe saponite (1b-c) in altered groundmass from the central part of the basalt flows. $2=$ Progressive change in the chemical composition of smectites found in the sediment in contact with basalt: detrital beidellite $(2 \mathrm{a}), \mathrm{Mg}$ saponite $(2 \mathrm{~b}-\mathrm{c})$, and $\mathrm{Al}$ saponite $(2 \mathrm{~d}-\mathrm{f}) .3-4=\mathrm{Clay}$ minerals in the chilled margin: Al saponite in the groundmass (3a-b) and infilling vesicles (3c-d); mixed-layer chlorite-smectite (4) infilling crack. 5a-b $\overline{\overline{3}}$ Chlorite infilling vesicles of tuffs. $6=$ Analcite as cement of vitric tuff. $-=$ not detected.

${ }^{\mathrm{a}} \mathrm{Fe}^{3+}$ as total iron.

$\mathrm{b} \mathrm{Fe}^{2+}$ as total iron.

processes of sediment transformation in contact with the basalt (sills or flows) have already been recorded in DSDP Leg 58, Leg 60, Leg 64, and Leg 65 (Chamley and Bonnot-Courtois, 1981; Desprairies, 1982; Kastner, 1982; Rangin et al., 1983). The occurrence of mixed-layer chlorite-smectite in the cracks and in contact with the basalt could indicate that the clay mineral transformation took place at a temperature around $200-230^{\circ} \mathrm{C}$ (Tomasson and Kristmanndottir, 1972; Kristmanndottir, 1976; Desprairies and Jehanno, in press).

\section{CONCLUSION}

The main common feature in the alteration products from the four Leg 81 sites is the widespread occurrence of a well-developed Mg-rich smectite (saponite). This clay mineral is associated with zeolites or other clays. Analcite is present in the tuffs from Hole 555 and analcite and chabazite occur in Hole 552. These mineral assemblages are encountered in reducing alteration conditions with the type of zeolites depending on the temperature.

In Holes 553 and 554, the saponite is associated with celadonite, which occurs in a more oxidizing alteration environment.

These mineralogical associations suggest different processes of alteration.

Hydrothermal alteration marked by saponite-celadonite assemblages affected first the basaltic sequence of Site 553 and was followed by subaerial weathering in the reddened levels with dioctahedral smectites and hematite. Classical palagonitization processes occur in basalts from Hole 554.
The oxidation of sediments overlying the basalts in Hole 552 is not obviously related to a volcanic intrusion or extrusion. On the contrary, the lack of oxidation processes in Hole 555 is in agreement with basaltic intrusion into the sedimentary sequence.

From Site 555 to Site 554, the basalts correspond to the transition between a rifting stage (Sites 555 and 553) and a spreading one (Site 554). At the beginning of the rifting, the Paleocene basalts from Site 555 are intruded in the form of sills in a very shallow-water environment. The same type of intrusion exists in Pleistocene sediments deposited in a deep-water environment (Legs 64 and 65, East Pacific Rise). At early Eocene age, (54.3 m.y. ago from paleomagnetic stratigraphy), the basaltic flows were extruded in a subaerial environment (Site 553) and were affected by hydrothermal processes. The early Eocene basalts from Site $\mathbf{5 5 2}$ may correspond to an intermediate stage between the rifting and the spreading periods. The palagonitization observed at Site 554 is in agreement with the low-temperature alteration of oceanic ridge tholeiitic basalts, but it appears here in a shallow water environment.

\section{REFERENCES}

Bonnot-Courtois, C., 1981. Distribution des terres rares dans les dépôts hydrothermaux de la zone FAMOUS et des Galapagos. Comparaison avec les sédiments métallifères. Mar. Geol., 39:1-14.

Chamley, H., and Bonnot-Courtois, C., 1981. Argiles authigènes et terrigènes de l'Atlantique et du Pacifique NW (Legs 11 et 58, DSDP): apport des terres rares. Oceanol. Acta, 4(2):229-238.

Chayla, B., Jaffrezic, H., and Joron, J. L., 1973. Analyse par activation dans les neutrons épithermiques. Application à la détermina- 
tion d'éléments en trace dans les roches. C. R. Hebd. Seances Acad. Sci., 277:273-275.

Courtois, C., and Desprairies, A., 1978. Les terres rares et quelques éléments de transition dans les minéraux argileux issus de deux processes d'altération de roches basiques. C. $R$. Somm. Seances Soc. Géol. Fr., 5:242-245.

Courtois, C., and Treuil, M., 1977. Distribution des terres rares et de quelques éléments en trace dans les sédiments récents des fosses de la Mer Rouge. Chem. Geol., 20:57-72.

Desprairies, A., 1982. Authigenic minerals in volcanogenic sediments cored during Deep Sea Drilling Project Leg 60. In Hussong, D. M., Uyeda, S., et al., Init. Repts. DSDP, 60: Washington (U.S. Govt. Printing Office), 455-466.

Desprairies, A., and Jehanno, C., in press. Paragenèses minérales liées à des interactions basalte-sédiment-eau de mer (Sites 465 et 456 des Legs 65 et 60 du DSDP). Sci. Géol.

Escande, M., 1983. Echangeabilité et fractionnement isotopique de l'oxygène des smectites magnésiennes de synthèse. Etablissement d'un géothermomètre [Thèse $3^{\circ}$ cycle] Université de Paris, Orsay.

Flanagan, F. J., 1976. Descriptions and analyses of eight new USGS Rock Standards. U.S. Geol. Surv. Prof. Pap., 840.

Foster, M. D., 1962. Interpretation of the composition and a classification of the chlorites. Geol. Surv. Prof Pap., 414-A:1-33.

Hoffert, M., Person, A., Courtois, C., Karpoff, A. M., and Trauth, D., 1980. Sedimentology, mineralogy and geochemistry of hydrothermal and sedimentary deposits from Holes 424, 424A, 424B and $424 \mathrm{C}$ (Galapagos Spreading Center). In Rosendahl, B. R., Hekinian, R. et al., Init. Repts. DSDP, 54: Washington (U.S. Govt. Printing Office), 339-376.

Honnorez, J., 1980. The aging of the oceanic crust at low temperature. In Emiliani, O. (Ed.), The Sea, (Vol. 7): New York (Wiley Interscience).

Juteau, T., Noack, Y., Whitechurch, H., and Courtois, C., 1980. Mineralogy and geochemistry of alteration products in Hole 417 A and 417D basement samples (Deep Sea Drilling Project Leg 51). In Donnelly, T., Francheteau, J., Bryan, W., Robinson, P., Flower, M., and Salisbury, M., et al., Init. Repts. DSDP, 51, 52, 53, Pt. 2: Washington (U.S. Govt. Printing Office), 1273-1297.

Kastner, M., 1982. Evidence for two distinct hydrothermal systems in the Guaymas basins. In Curray, J. R., Moore, D. G., et al., Init. Repts. DSDP, 64: Washington (U.S. Govt. Printing Office), 1143-1157.

Kristmanndottir, H., 1976. Types of clay minerals in hydrothermal altered basaltic rocks, Reykjanes Iceland. Jökull, 26:30-39.
Kristmanndottir, H., and Tomasson, J., 1978. Zeolite zones in geothermal areas in Iceland. In Sand, L. B., and Mumpton, F. (Eds.), Natural Zeolites, Occurrences, Properties, Use: Oxford (Pergamon Press), pp. 199-220.

Mottl, J. M., and Holland, H. D., 1978. Chemical exchange during hydrothermal alteration of basalt by seawater. I. Experimental results for major and minor components of seawater. Geochim. Cosmochim. Acta, 42:1103-1115.

Noack, Y., 1981. La palagonite: caractéristiques, facteurs d'évolution et mode de formation. Bull. Mineral., 104:36-46.

Person, A., 1976. Recherches sur les néoformations argileuses dans l'environnement volcanique [Thèse de $3^{\circ}$ cycle]. Université de Paris, Paris.

Rangin, C., Desprairies, A., Fontes, J. Ch., Jehanno, C., and Vernhet, S., 1983. Metamorphic processes in sediments in contact with young oceanic crust. East Pacific Rise Leg 65. In Lewis, B. T. R., Robinson, P., et al., Init. Repts. DSDP, 65: Washington (U.S. Govt. Printing Office), 375-389.

Savin, S. M., Douglas, R. G., Keller, G., Killingley, J. S., Shaughnessey, L., Sommer, M. A., Vincent, E., and Woodruff, F., 1981. Miocene benthic foraminiferal isotope records: a synthesis. Mar. Micropaleontol., 6:423-450.

Scheidegger, K. F., and Stakes, D. S., 1977. Mineralogy, chemistry and crystallization sequence of clay minerals in altered tholeiitic basalts from the Peru trench. Earth Planet. Sci. Lett., 36:413-422.

Seyfried, W. E., Shanks, W. C., and Dibble, W. E. 1978. Clay mineral formation in DSDP Leg 34 basalt. Earth Planet. Sci. Lett., 41: 265-276.

Seyfried, W. E., and Bischoff, J. L., 1979. Low temperature basalt alteration by seawater: an experimental study at $70^{\circ} \mathrm{C}$ and $150^{\circ} \mathrm{C}$. Geochim. Cosmochim. Acta, 43:1937-1947.

Tomasson, J., and Kristmanndottir, H., 1972. High-temperature alteration minerals and thermal brines, Reykjanes, Iceland. Contrib. Mineral. Petrol., 36:123-134.

Treuil, M., Jaffrezic, H., Deschamp, N., Derre, C., Guichard, F., Joron, J. L., Pelletier, B., Novotny, S., and Courtois, C., 1973. Analyse des lanthanides, du hafnium, du scandium, du chrome, du manganèse, du cobalt, du cuivre et du zinc dans les minéreaux et les roches par activation neutronique. J. Radioanal. Chem., 18: 55-68.

Date of Acceptance: October 12, 1983 

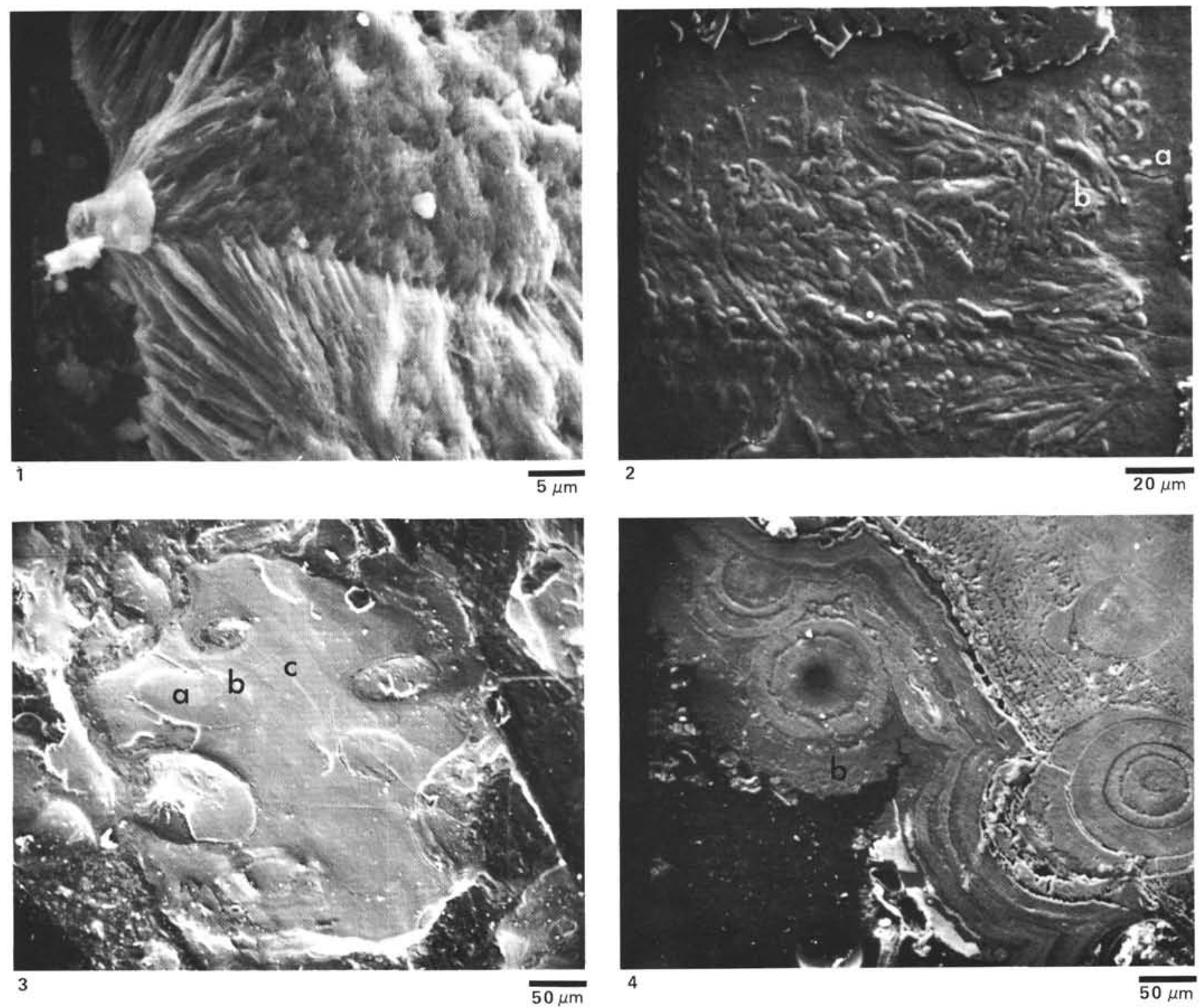

Plate 1. 1. Sample 553A-38-2, 60-63 cm. Authigenic saponite infilling vesicle of basalt. Analysis (4a) in Table 2. 2. Sample 553A-50-3, 60-62 cm. Authigenic saponite (a) and celadonite (b) infilling vesicle of volcanic breccia. Analyses (5a-5b) in Table 3. 3. Sample 553A-45-1, 35-38 cm. Reddened tuff. Vesicle with a core of iron-rich beidellite (a) and a rim of iron-rich saponite (b); altered glass (c). Analyses (8a-d) in Table 3. 4. Sample 555-92-1, 29-35 cm. Authigenic chlorite (b) in vitric tuff. Analysis (5) in Table 8. 